\title{
Effect of processing whole cottonseed on yield and composition of milk in dairy cows*
}

\author{
P. Chen, P. Ji, Z.J. Cao and S.L. Li ${ }^{1}$ \\ State Key Laboratory of Animal Nutrition, College of Animal Science \& Technology, \\ China Agricultural University \\ Beijing 100094, P.R. China
}

\begin{abstract}
Four Holstein cows were used in a $4 \times 4$ Latin square design to determine the effect of feeding different processing whole cottonseed (WCS) on milk yield, milk composition and milk fatty acid profile. Result showed that dry matter intake and milk yield were unaffected by different treatments, but milk protein concentrations were increased in cows fed processing WCS diets. Compared with control, feeding cows with different processing WCS diets reduced C14:0 and C16:0 and elevated C18:0 and C18:1 in milk, and feeding extruded delinted WCS increased C18:2 and cis9, trans 11 conjugated linoleic acid in milk.
\end{abstract}

KEY WORDS: whole cottonseed, processing, milk yield, milk composition, conjugated linoleic acid, dairy cows

\section{INTRODUCTION}

Whole cottonseed (WCS) is commonly included in the diet of lactating dairy cows as a source of fat, protein and fibre (Harvatine et al., 2002). The supplemental fat from WCS increases the energy density of the diet, and the protein and oil contained in the seed are released slowly during mastication and to decrease the degradation in the rumen and increase milk protein and milk yield (Mabjeesh et al., 2000).

Recent research has focused on increasing the amount of polyunsaturated fatty acids (PUFA) and conjugated linoleic acid (CLA) in milk fat because of reported health benefits (Ip et al., 1999). Mabjeesh et al. (2000) demonstrated that feeding roasted delinted WCS was more effective in creasing milk fat content of cis 9 , trans11-CLA than feeding linted WCS. Reveneau et al. (2005) concluded that

\footnotetext{
* Supported by the National Dairy Key Technologies R \& D Programme for the 11th Five-Year Plan, Grant No. 2006BAD04A03

${ }^{1}$ Corresponding author: e-mail: lisheng0677@vip.sina.com
} 
feeding small WCS pellets was more effective in increasing milk fat content of cis9, trans 11-CLA than feeding large WCS pellets. Dhiman et al. (1999) found that milk fat content of cis9, trans11-CLA was increased in the extruded WCS treatment compared with control. A wide range of positive health effect has been demonstrated for PUFA and CLA to lower insulin resistance associated with cardiovascular disease (Kennelly, 1996). Thus, increasing the concentration of PUFA and CLA in milk may be beneficial to public health and enhance the consumption of dairy products.

However, the data on the relationship between processing WCS and milk fatty acids profile are usually studied in early lactation dairy cows. Much less information is available concerning midlactation cows. The present study was designed to assess the effects of linted, delinted and extruded delinted WCS on milk yield and milk composition in midlactation cows.

\section{MATERIAL AND METHODS}

Four Holstein cows averaging $105( \pm 28)$ days in milk (DIM) were used for one of the four treatment groups in a $4 \times 4$ Latin square design with four 3 -wk periods. The first $16 \mathrm{~d}$ of each period were for adaptation to diets and the last $5 \mathrm{~d}$ were for sample collection. The cows were kept in stalls with free access to water.

Dietary treatments consisted of a control diet with no WCS (CON) and three diets in which 11\% linted WCS (LCS), 11\% delinted WCS (DCS) and 11\% extruded delinted WCS (ECS) were supplemented, respectively. Diets were fed as total mixed ration (TMR) with maize silage, dry lucerne and dry Chinese wild rye as forage and maize, soyabean, bran, salt, processing WCS and premix as concentrate. All diets contained similar levels of crude protein (CP, 15\%), neutral detergent fibre (NDF, $37 \%$ ) and acid detergent fibre (ADF, 24\%), and were formulated to meet nutrient requirements of midlactating dairy cows (NRC, 2001). Cows were fed ad libitum three times daily and amounts fed and refused were recorded daily.

Cows were milked three times daily, with individual milk weights recorded. Milk samples of each cow's were collected daily during collection period. Milk fat, protein, lactose and solids-non-fat (SNF) were determined by near-infrared spectroscopy (Foss MikoScan 4000; Foss Technology, Eden Prairie, MN), and for analysis of somatic cell count (SCC, Fossomatic 5000; Foss Technology). Milk urea $\mathrm{N}$ (MUN) was determined on defatted milk samples using the method described by Crocker (1967). The remaining portion was stored at $-20^{\circ} \mathrm{C}$ for fatty acids analysis.

Fatty acids of experimental diets and different processing WCS (Table 1) were extracted and methylated by the one-step procedure (Sukhija and Palmquist, 1988) using hexane instead of benzene. Lipids from the milk were extracted with chloroform/methanol according to the method described by Lin et al. (2003). Fatty 
acids were quantified by incorporating internal standard, heptadecanoic (C17:0) acid methyl esters (Sigma, St Louis, MO) into each sample. The fatty acids were methylated with $\mathrm{NaOCH}_{3} /$ methanol at $50^{\circ} \mathrm{C}$ for $30 \mathrm{~min}$ and $\mathrm{HCl} /$ methanol at $60^{\circ} \mathrm{C}$ for $1 \mathrm{~h}$, using the method described by Magdi (2001). The fatty acid methyl esters (FAME) of feeds and milk samples were separated by gas chromatography GLC (6890 N, Agilent technologies), on a $60 \mathrm{~m}$ Supelco SP 2560 (Supelco, Bellefonte, PA) capillary column $(0.25 \mathrm{~mm}$ i.d. and $0.20 \mathrm{~mm}$ film thickness $)$ with a split ration of $20: 1$, using helium as carrier gas. Column oven initial temperature was $180^{\circ} \mathrm{C}$ (held for $10 \mathrm{~min}$ ), increased by $4^{\circ} \mathrm{C}$ per min, and then was held at $220^{\circ} \mathrm{C}$ for 15 min. The injector and detector temperature were maintained at $250^{\circ} \mathrm{C}$. Peaks of CLA isomers and other PUFA were identified by comparison of retention times with standards from Sigma (St. Louis, MO).

Table 1. Fatty acid profile of experiment diets and different processing whole cottonseed, $\mathrm{g} / 100 \mathrm{~g}$ of fatty acid

\begin{tabular}{|c|c|c|c|c|c|c|c|}
\hline \multirow{2}{*}{ Item } & \multicolumn{4}{|c|}{ Experimental treatments $^{1}$} & \multicolumn{3}{|c|}{ Processing WCS } \\
\hline & $\mathrm{CON}$ & LCS & DCS & ECS & linted & delinted & extruded \\
\hline C14 16 & 20.63 & 22.97 & 22.99 & 22.73 & 24.99 & 24.24 & 25.07 \\
\hline C18:0 & 3.54 & 2.90 & 2.89 & 2.89 & 2.38 & 2.33 & 2.22 \\
\hline C18:1 & 20.79 & 17.92 & 17.89 & 18.18 & 15.59 & 15.18 & 15.52 \\
\hline C18:2 & 41.21 & 48.72 & 48.81 & 47.95 & 55.77 & 57.06 & 56.03 \\
\hline $\mathrm{C} 18: 3$ & 9.47 & 4.84 & 4.78 & 5.46 & 0.21 & 0.19 & 0.26 \\
\hline cis9, trans11-CLA & 0.13 & 0.07 & 0.07 & 0.07 & 0.04 & 0.03 & 0.03 \\
\hline Others ${ }^{2}$ & 4.22 & 2.57 & 2.57 & 2.72 & 1.02 & 0.94 & 0.85 \\
\hline
\end{tabular}

${ }^{1}$ CON - control, LCS - linted WCS, DCS - delinted WCS, ECS - extruded delinted WCS

${ }^{2}$ fatty acids from $\mathrm{C} 20$ to $\mathrm{C} 22$ fatty acid

Data analysed using the GLM procedure of SAS (1999) for Latin square with affects of periods and treatments, the random effect was cow. Significance was declared at $\mathrm{P}<0.05$.

\section{RESULTS AND DISCUSSION}

Daily dry matter intake (DMI) and milk yield were not significantly different among treatments ( $\mathrm{P}>0.05$; Table 2$)$, however, the milk yield of cows fed ECS diet was higher $1.5 \mathrm{~kg} / \mathrm{d}$ than cows fed CON. These results were consistent with other reports (Dhiman et al., 1999; Moreira et al., 2004; Reveneau et al., 2005).

Milk fat was not affected in cows receiving all kind of WCS diets $(\mathrm{P}>0.05)$. Previous studies showed that supplement of linted WCS, delinted WCS (Moreira et al., 2004; Reveneau et al., 2005) or extruded WCS (Dhiman et al., 1999) also had no effect on milk fat. 
Milk protein often decreases when supplemental fat is fed to lactating dairy cows (Dhiman et al., 1999; Johnson et al., 2002). However, we observed that the milk protein was increased when cows were fed delinted and extruded WCS $(\mathrm{P}<0.05)$, which was consistent with some previous reports (Mabjeesh et al., 2000; Reveneau et al., 2005). This can be explained that microbial protein synthesis was improved when cows were fed processing WCS, resulting in an increase of protein flow in the small intestine. Consequently, there was an improvement of the flow of amino acids to the mammary gland and a high milk protein content (Harvatine et al., 2002).

Cows fed the ECS diet had higher MUN concentration $(\mathrm{P}<0.05)$. Johnson et al. (2002) reported that MUN was increased when cows were fed with oilseed. It is likely that free oil of extruded WCS has negative effect on rumen microbial protein and more nitrogen is absorbed across the ruminal wall and synthesized into MUN by the mammary gland (Mabjeesh et al., 2000). Milk lactose was not affected by the dietary factors $(\mathrm{P}>0.05)$.

Table 2. Dry matter intake, milk yield and milk composition of dairy cows fed different diets

\begin{tabular}{|c|c|c|c|c|c|c|}
\hline \multirow{2}{*}{ Item } & \multicolumn{4}{|c|}{ Experimental treatments } & \multirow{2}{*}{ SEM } & \multirow{2}{*}{$\mathrm{P}$} \\
\hline & $\mathrm{CON}$ & LCS & DCS & ECS & & \\
\hline DMI, kg/d & 15.96 & 15.98 & 16.49 & 16.92 & 0.48 & 0.58 \\
\hline Milk yield, $\mathrm{kg} / \mathrm{d}$ & 19.04 & 18.76 & 19.47 & 20.54 & 0.96 & 0.35 \\
\hline Milk fat, \% & 3.54 & 3.72 & 3.96 & 3.77 & 0.14 & 0.18 \\
\hline Milk protein, $\%$ & $3.36^{\mathrm{b}}$ & $3.49^{\mathrm{ab}}$ & $3.62^{\mathrm{a}}$ & $3.61^{\mathrm{a}}$ & 0.06 & 0.001 \\
\hline Milk lactose, $\%$ & 4.33 & 4.38 & 4.13 & 4.27 & 0.07 & 0.16 \\
\hline MUN, mg/l & $125.85^{\mathrm{b}}$ & $122.30^{\mathrm{b}}$ & $120.82^{\mathrm{b}}$ & $135.71^{\mathrm{a}}$ & 2.73 & 0.048 \\
\hline
\end{tabular}

a,b means within a row with different superscripts differ $(\mathrm{P}<0.05)$

Compared with CON, feeding different processing WCS diets reduced $\mathrm{C} 14$ to $\mathrm{C} 16$ fatty acids in milk (Table 3; $\mathrm{P}<0.05$ ). This result was consistent with previous reports (Dhiman et al., 1999; Reveneau et al., 2005). Medium-chain fatty acids are mainly de novo synthesized in mammary gland of cows, and are susceptible to inhibition when increasing dietary levels of certain PUFA (Kennelly, 1996).

Table 3. Milk fatty acids profiles of dairy cows fed different diets

\begin{tabular}{|c|c|c|c|c|c|c|}
\hline \multirow{2}{*}{$\mathrm{g} / 100 \mathrm{~g}$ of fatty acid } & \multicolumn{4}{|c|}{ Experimental treatments } & \multirow{2}{*}{ SEM } & \multirow{2}{*}{$\mathrm{P}$} \\
\hline & $\mathrm{CON}$ & LCS & DCS & ECS & & \\
\hline C14 16 & $49.31^{\mathrm{a}}$ & $40.71^{\mathrm{b}}$ & $40.99^{\mathrm{b}}$ & $39.84^{b}$ & 1.07 & 0.03 \\
\hline C18:0 & $16.06^{\mathrm{b}}$ & $20.85^{\mathrm{a}}$ & $20.20^{\mathrm{a}}$ & $20.20^{\mathrm{a}}$ & 0.57 & 0.04 \\
\hline C18:1 & $29.70^{\mathrm{b}}$ & $34.32^{\mathrm{a}}$ & $33.46^{\mathrm{a}}$ & $34.20^{\mathrm{a}}$ & 0.93 & 0.04 \\
\hline C18:2 & $2.70^{\mathrm{b}}$ & $2.76^{\mathrm{b}}$ & $2.91^{\mathrm{b}}$ & $3.45^{\mathrm{a}}$ & 0.04 & 0.03 \\
\hline $\mathrm{C} 18: 3$ & 0.40 & 0.37 & 0.39 & 0.40 & 0.04 & 0.91 \\
\hline cis 9 , trans 11-CLA & $0.66^{\mathrm{b}}$ & $0.68^{\mathrm{b}}$ & $0.77^{\mathrm{ab}}$ & $1.00^{\mathrm{a}}$ & 0.03 & 0.04 \\
\hline Others $^{1}$ & 1.17 & 1.11 & 1.28 & 0.91 & 0.29 & 0.34 \\
\hline
\end{tabular}

a,b means within a row with different superscripts differ $(\mathrm{P}<0.05) ;{ }^{1}$ fatty acids from $\mathrm{C} 20$ to $\mathrm{C} 22$ fatty acid 
The concentrations of $\mathrm{C} 18: 0$ and $\mathrm{C} 18: 1$ in milk fat from cows fed different processing WCS diets were higher than that from cows fed the CON $\operatorname{diet}(\mathrm{P}<0.05)$. This is in a harmony with the previous reports (Dhiman et al., 1999; Reveneau et al., 2005). The average increase in the proportion of C18:1 in milk of the three treatments can be attributed to higher concentration of C18:2 fatty acids in WCS diets, which would increase the $\mathrm{C} 18: 1$ fatty acid content in the milk through rumen biohydrogenation (Dhiman et al., 1999).

The proportions of C18:2 and cis9, trans11-CLA in the milk of cows fed ECS diet were higher than those in the milk of cows from all other treatments $(\mathrm{P}<0.05)$. Dhiman et al. (1999) observed the similar result. WCS is rich in C18:2 and C18:3 fatty acids which may serve as the precursors for cis 9 , trans 11 -CLA by ruminal biohydrogenation (Griinari et al., 1999). However, in this study, neither LCS nor DCS diet influence the C18:2, C18:3 or cis9, trans11-CLA concentration in milk $(\mathrm{P}>0.05)$. This is likely the result that dietary oil in the form of intact seeds does not change milk CLA content and the hydrolysis and hydrogenation of C18:2 or C18:3 by ruminal microorganisms (Dhiman et al., 1999), or, more likely, oil released from the raw WCS is not as readily available as oil from the process of extrusion, thus affecting subsequent availability of the oil to ruminal microbes. The increase in milk PUFA suggests a portion of the oil escaped ruminal metabolism and saturation.

\section{CONCLUSIONS}

Supplementation with processing whole cottonseed (WCS) to cows did not affect dry matter intake or milk yield but increase milk protein. Feeding cows with different processing (linted, delinted and extruded linted) WCS diets could potentially increase the desirable polyunsaturated fatty acid in milk, and feeding extruded delinted WCS could increased cis9, trans 11-CLA in milk.

\section{REFERNECES}

Crocker C.L., 1967. Rapid determination of urea nitrogen in serum or plasma without deproteinization. Amer. J. Med. Technol. 33, 361-365

Dhiman T.R., Helmink E.D., McMahon D.J., Fife R.L., Pariza M.W., 1999. Conjugated linoleic acid content of milk and cheese from cows fed extruded oilseeds. J. Dairy Sci. 82, 412-419

Griinari J.M., Nurmela K.V., Dwyer D.A., Barbano D.M., Bauman D.E., 1999. Variation of milk fat concentration of conjugated linoleic acid and milk fat percentage is associated with a change in ruminal biohydrogenation. J. Anim. Sci. 77, Suppl. 1, 117 (Abstr.)

Harvatine D.I., Firkins J.L., Eastridge M.L., 2002. Whole linted cottonseed as a forage substitute fed with ground or steam-flaked corn: digestibility and performance. J. Dairy Sci. 85, 1976-1987 
Ip C., Banni S., Angioni E., Carta G., McGinley J., Thompson H.J., Barbano D., Bauman D., 1999. Conjugated linoleic acid-enriched butter fat alters mammary gland morphogenesis and reduces cancer risk in rats. J. Nutr. 129, 2135-2142

Johnson K.A., Kincaid R.L., Westberg H.H., Gaskins C.T., Lamb B.K., Cronrath J.D., 2002. The effect of oilseeds in diets of lactating cows on milk production and methane emissions. J. Dairy Sci. 85, 1509-1515

Kennelly J.J., 1996. The fatty acid composition of milk fat as influenced by feeding oilseeds. Anim. Feed Sci. Tech. 60, 137-152

Lin T.Y., Lin C.W., Wang Y.J., 2003. Production of conjugated linoleic acid by enzyme extract of Lactobacillus acidophilus CCRC 14079. Food Chem. 83, 27-31

Mabjeesh S.J., Galindez J., Kroll O., Arieli A., 2000. The effect of roasting nonlinted whole cottonseed on milk production by dairy cows. J. Dairy Sci. 83, 2557-2563

Magdi M.M., 2001. Analytical techniques for conjugated linoleic acid (CLA) analysis. Eur. J. Lipid Sci. Technol. 103, 594-594

Moreira V.R., Satter L.D., Harding B., 2004. Comparison of conventional linted cottonseed and mechanically delinted cottonseed in diets for dairy cows. J. Dairy Sci. 87, 131-138

NRC, 2001. Nutrient Requirements of Dairy Cattle. 7th Edition. National Academy of Sciences. Washington, DC

Reveneau C., Ribeiro C.V.D.M., Eastridge M.L., St-Pierre N.R., Firkins J.L., 2005. Processing whole cottonseed moderates fatty acid metabolism and improves performance by dairy cows. J. Dairy Sci. 88, 4342-4355

SAS, 1999. SAS User's Guide: Statistics. Version 8 Ed. Institute Inc. Cary, NC

Sukhija P.S., Palmquist D.L., 1988. Rapid method for determination of total fatty acid content and composition of feedstuffs and feces. J. Agr. Food Chem. 36, 1202-1206 